Article

\title{
From TRMM to GPM: How Reliable Are Satellite-Based Precipitation Data across Nigeria?
}

\author{
Pius Nnamdi Nwachukwu ${ }^{1,2, *}$, Frederic Satge ${ }^{2}$, Samira El Yacoubi ${ }^{1,2}$, Sebastien Pinel ${ }^{3}$ (i) and \\ Marie-Paule Bonnet ${ }^{2}$ (D) \\ 1 IMAGES-ESPACE-DEV, Faculty of Exact and Experimental Sciences, University of Perpignan Via Domitia, \\ 52 Avenue Paul Alduy, CEDEX 9, 66860 Perpignan, France; yacoubi@univ-perp.fr \\ 2 Espace-DEV, IRD, University of Montpellier, 34093 Montpellier, France; frederic.satge@ird.fr (F.S.); \\ marie-paule.bonnet@ird.fr (M.-P.B.) \\ 3 Centre of Education and Research on Mediterranean Environments (CEFREM), University of Perpignan, \\ 52 Avenue Paul Alduy, CEDEX 9, 66860 Perpignan, France; sebastien.pinel@univ-perp.fr \\ * Correspondence: pius.nwachukwu@univ-perp.fr
}

Received: 6 November 2020; Accepted: 24 November 2020; Published: 3 December 2020

check for updates

\begin{abstract}
In this study, 16 satellite-based precipitation products (SPPs) comprising satellite, gauge and reanalysis datasets were assessed on a monthly time step using precipitation data from 11 gauge stations across Nigeria within the 2000-2012 period as reference. Despite the ability of some of the SPPs to reproduce the salient north-south pattern of the annual rainfall field, the Kling-Gupta efficiency (KGE) results revealed substantial discrepancies among the SPP estimates. Generally, the SPP reliability varies spatially and temporally, with all SPPs performing better over part of central Nigeria during the dry season. When we compared the real-time and adjusted satellite-based products, the results showed that the adjusted products had a better KGE score. The assessment also showed that the reliability of integrated multi-satellite retrievals for Global Precipitation Mission (IMERG) products was consistent with that of their predecessor Tropical Rainfall Measuring Mission (TRMM) multi-satellite precipitation analysis (TMPA). Finally, the best overall scores were obtained from multi-source weighted-ensemble precipitation (MSWEP) v.2.2 and IMERG-F v.6. Both products are therefore suggested for further hydrological studies.
\end{abstract}

Keywords: satellite precipitation; gauge; validation; Nigeria

\section{Introduction}

\subsection{Precipitation Monitoring Across Remote Regions}

Accurate measurements of precipitation across space and time remain essential to assess its deficits and abundance. Such measurements allow for tracking the state of precipitation and its overall effect on hydro-ecological systems and water resource management [1,2]. At the global level, precipitation information is necessary for sustainable socio-economic growth, especially in countries with lower rainfall regimes and in some developing nations that depend on rainfall for socio-economic purposes such as agriculture [3,4]. The high spatial and temporal variability of precipitation requires a formidable network of gauge installations to monitor the occurrence and intensity of rainfall effectively. However, in many countries, precipitation information has traditionally been collected from a sparsely distributed network of gauge stations. The scarcity of large numbers of these gauges has resulted in spatially and temporarily discontinuous observations [5,6]. Some authors [7-9] also claimed that the socio-economic and challenging terrain contexts had hindered the installation and management of gauge stations, emphasising data breaches in many locations. In this context, precipitation data from 
gauge station observations are inadequate in many parts of the developing world [10,11]. Hence, there is a need to fill the data gap created in the absence of reliable precipitation from the gauge stations.

\subsection{Satellite-Based Precipitation Estimate Prospect}

Recent advancements in remote sensing technologies have led to the development of satellite precipitation products (SPP) which measure precipitation on a regular grid globally [12,13], offering ample opportunity to overcome the problems associated with traditional gauge measurements. In recent decades, several efforts to improve SPPs in terms of precipitation accuracy, temporal and spatial resolution, and extension of temporal coverage have been presented.

The first generation of SPPs started with the Tropical Rainfall Measuring Mission (TRMM) launched in 1997 by the National Aeronautics and Space Administration (NASA), and the Japan Aerospace Exploration Agency (JAXA). Over the last 20 years, TRMM multi-satellite precipitation analysis (TMPA) [14,15], Climate Prediction Centre MORPHing (CMORPH) [16], and precipitation estimation from remotely sensed information using artificial neural networks (PERSIANN) [17] SPPs have been developed based on the TRMM to deliver precipitation estimates at the $0.25^{\circ}$ grid scale.

The second generation of SPPs, the Global Precipitation Mission (GPM), was launched in 2014 to overcome the technical difficulties arising from ageing mechanisms and sensors of the TRMM to ensure the continuation of precipitation data acquisition. The second generation of SPPs included the integrated multi-satellite retrievals for GPM (IMERG) [18] and Global Satellite Mapping of Precipitation (GSMaP) SPPs which deliver precipitation estimates at a finer grid scale $\left(0.1^{\circ}\right)$ than the first generation of SPPs.

At the same time, the third generation of SPPs took advantage of previous SPPs and missions to estimate precipitation over a larger time window; hence, the long-term SPP generation. This is the case of PERSIANN-Climate Data Record (PERSIANN-CDR), multi-source weighted-ensemble precipitation (MSWEP), Climate Hazards Group Infrared Precipitation (CHIRP) with station data (CHIRPS) available at a global scale, tropical applications of meteorology using satellite and ground-based observation (TAMSAT), and African Rainfall Climatology (ARC v.2), only covering the African continent. Despite continuous efforts to improve SPP reliability, these products are subject to uncertainties in space and over time due to technical issues relating to sensitivity to the topography, i.e., $[19,20]$, surface temperature and emissivity contrast, i.e., [21-23], and regional differential climatologic context, i.e., [24-26]. In these circumstances, numerous studies on the reliability of SPPs in many parts of the world have provided vital information to potentially interested users [27]. This effort comes with first studies reporting on the first generation of SPPs based on the TRMM, i.e., [28-33].

Then, from 2014, studies started to report on the second generation of SPPs based on the GPM. These studies highlight the potential benefits of the GPM over the TRMM [30,33-39]. At the same time, other studies reported on long-term SPPs to monitor drought processes and precipitation trends in order to understand the sensitivity of water resources to ongoing climate variability potential [40-42].

\subsection{Toward a Broad Overview of Satellite-Based Precipitation Reliability across Nigeria}

As indicated earlier, most of the available studies reported on the reliability of a single SPP group such as TRMM, GPM, and long-term. Although all the SPPs have been available since the start of the satellite precipitation mission (2000-present), it is essential to compare their reliability to indicate the most reliable SPP among the available products. In this circumstance, such effort is only possible by crossing results from studies in different regions and temporal windows. However, such action prevents a robust comparison, as SPP sensitivity to the regional meteorological, topographic, and land cover characteristics induce substantial space and time reliability variation [26,43,44]. A recent study comparing seven satellite-based precipitation datasets over two distinct areas with similar precipitation patterns (i.e., South American Andean Plateau and Pakistan) shows that the most reliable SPP from one region to another is different [45]. 
In Nigeria, there are few studies focusing on SPP validation, but each has had a specific purpose. For instance, using gauge data as a reference, Semire et al. (2013) [46], evaluated one first-generation SPP (TMPA v.7) using gauge data as a baseline. Similarly, Akinyemi et al. (2019) [47] evaluated one long-term SPP (CHIRPS) along with RFE 2.0, and Usman et al. (2018) [48] analysed four SPPs' (TAMSAT v.2, ARC v.2, TMPA v.7, and CHIRPS v.2) ability to follow spatio-temporal precipitation trends in northern Nigeria. Consequently, the reliability assessment of SPPs across Nigeria is limited in terms of products (TAMSAT v.2, ARC v.2, TMPA v.7, CHIRPS v.2) and spatial coverage.

\subsection{Study Objectives}

The main goal of this study is to assess for the first time the performances of sixteen SPPS (including TRMM, GPM, and long-term SPPs) over Nigeria for thirteen years. This study also addresses the improvement of first- to second-generation SPPs (TRMM to GPM) and to compare these products with the recently released long-term SPP for a standard observation period.

In a general context, this study will provide useful information to guide potential interested SPP users at the time of choosing the most efficient SPPs for their research but also precious information for SPP team developers to improve future SPP generation.

\section{Materials}

\subsection{Study Area}

Nigeria is a country in West Africa, located within latitude $4^{\circ} .00-14^{\circ} .00$ north of the equator and longitude $3^{\circ} .00-15^{\circ} .00$ east of the meridian. It is bordered to the north by the Niger Republic and the Chad Republic, to the east and west by Cameroon and the Benin Republic, and in the south by the Atlantic Ocean. Nigeria has a rainfall regime that varies spatially and temporally.

Annual precipitation varies from about $\leq 900 \mathrm{~mm} /$ year in the northern region to over $4000 \mathrm{~mm} / \mathrm{year}$ in the southern part. Nigeria can be divided into three main climatic zones: (i) the Guinea Coast $\left(4^{\circ}-8^{\circ} \mathrm{N}\right)$, (ii) the Savannah $\left(8^{\circ}-11^{\circ} \mathrm{N}\right)$, and (iii) the Sahel $\left(11^{\circ}-16^{\circ} \mathrm{N}\right)[49,50]$ (Figure 1). Precipitation starts around March/April in the Guinea region and ends by October each year. However, in both Savannah and Sahel regions, precipitation sets off around May/June and ends in September (Figure 1). The Guinea and Savannah areas experience double maxima, with a small break in August (Figure 1), known in Nigeria as August break [51]. It is worth noting that generally in Nigeria, precipitation is governed by the actions of the West African monsoon, characterised by variations in the maritime and continental air masses, referred to as south-westerly and north-easterly winds, respectively [52]. This monsoon action summarises the known rainfall regime known in Nigeria.

Vegetation types vary from the Sahel in the northwest, Sudan Savannah stretching to some of the north-western, north-central, and north-eastern parts of Nigeria. The Guinea/rainforest region starts from the southern part of the middle belt, extending into the stretch of the Niger Delta in the south. As with the vegetation, the topography varies within the country. Parts of the south-west consist of complex and rugged rocky terrain. The topography of the north-east is a combination of highlands, such as the Mambila and Adamawa, and the Jos Plateau. There are also the Obudu highlands on the southern border with Cameroon. Most of the coastal fronts consist of swampy terrain of the south. The most important rivers are the Niger and the Benue. Both have formed a confluence in the low-lying plains of the north-central town of Lokoja. 


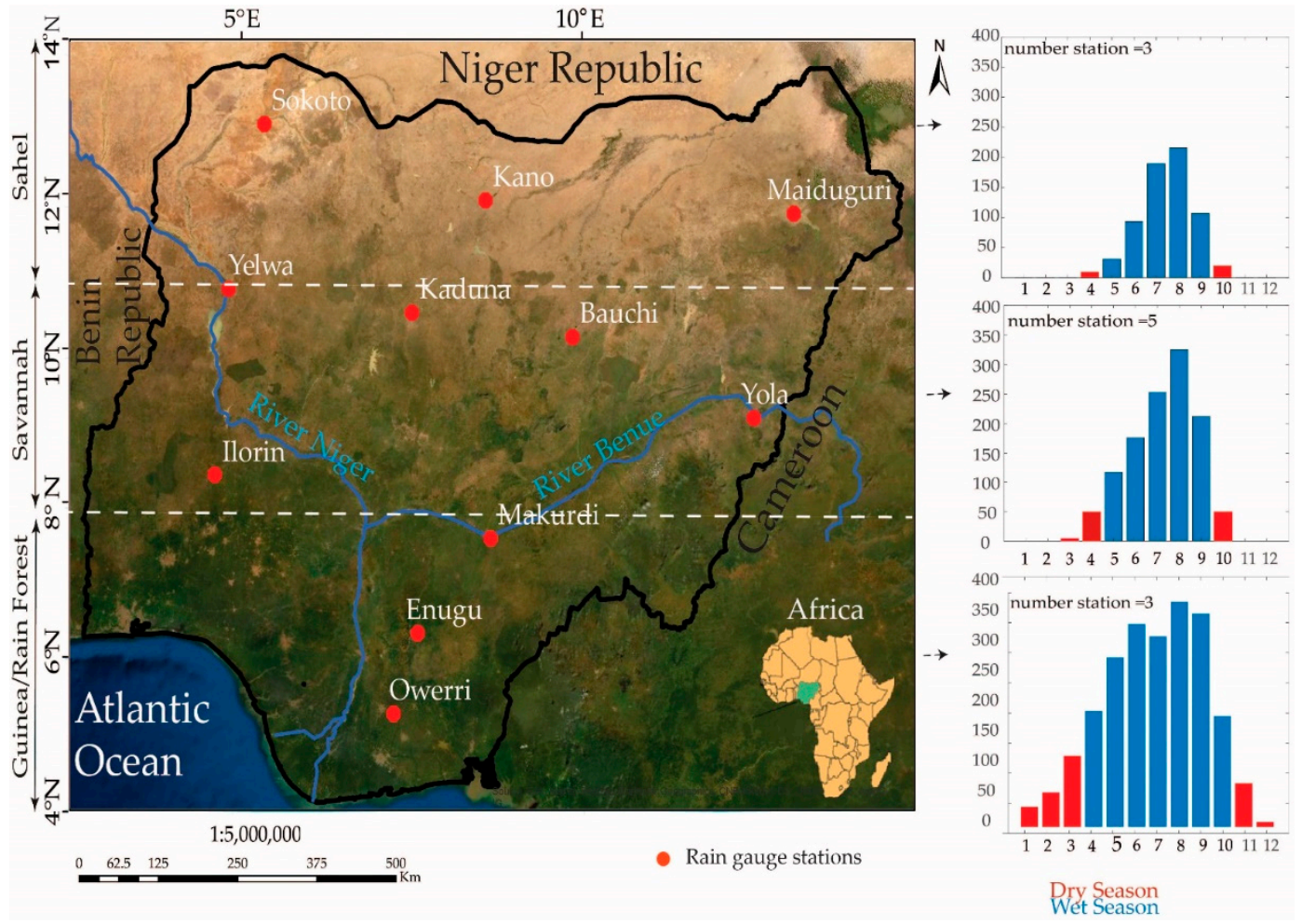

Figure 1. A map of Nigeria showing the locations and names of reference meteorological gauge stations and precipitation distribution among the meteorological zones of the country.

\subsection{Rain Gauge Observations}

Gauge precipitation observations were collected from eleven (11) meteorological stations (Figure 1) managed by the Nigerian Meteorological Agency (NIMET). NIMET uses measuring cylinders attached to rain gauges for measuring rainfall in the majority of their stations across Nigeria. Precipitation is measured daily and further harmonised into a weekly and monthly dataset. Although the gauge reference data were not collected from all stations across the country, the selected gauge stations are well distributed from the Sahel to the southern part of the Guinea/rainforest region.

\subsection{Brief Descriptions of the Satellite-Based Precipitation Products}

Table 1 shows the main characteristics of the sixteen satellite-based precipitation products (SPPs) used in this work. The SPPs were downloaded from their host websites which are free and open source. The 16 considered SPPs include:

- The Tropical Rainfall Monitoring Mission (TRMM) covering the last 20 years at $0.25^{\circ}$ spatial resolution;

- $\quad$ The Global Precipitation Mission (GPM) covering the previous 20 years at $0.1^{\circ}$ spatial resolution; - The long-term datasets are reanalysed retrospectively (40 years).

The first and second SPP generation (TRMM and GPM) combine passive (and active) microwaves (PMWs) with infrared sensors on board a low Earth-orbital (LEO) satellite and geostationary satellite, respectively, to retrieve precipitation estimates. This combination aims to optimise precipitation estimates and fill space and time gaps related to the limited overpass of the LEO satellite.

The long-term SPPs merge reanalysis datasets derived from physical and dynamical models with satellite-based precipitation estimates. The reanalysis datasets are available for a larger temporal window than the PMW and IRs sensor used for TRMM and GPM SPPs. Therefore, the long-term SPPs offer more extensive temporal coverage than TRMM and GPM SPPs. Generally, the relationship between reanalysis datasets and satellite-based precipitation estimates from TRMM SPPs and IR-based 
precipitation estimates are known for a standard period of observation. This information encourages retrospectively reanalysed estimates of past precipitation events. Finally, it is worth mentioning that most of the considered SPPs also include a gauge-based precipitation dataset to calibrate the precipitation estimates. Therefore, the 16 considered SPPs include (1) only satellite-based SPPs (PERSIANN-RT, TMPA-RT v.7, IMERG-E, and -L v.6), (2) satellite-based SPPs adjusted with gauge information, such as TMPA-Adj v.6, IMERG-F v.6, CMORPH-CRT and -BLD v.1, TAMSAT v.3, and ARC-2, and (3) SPPs including both satellite and reanalysis datasets with or without gauge adjustment (CHIRP v.2, CHIRPS v.2, PERSIANN-CDR, and MSWEP v.2.2).

For more information about the considered SPPs, readers should refer to the main references listed in Table 1.

Figure 2 shows the mean annual precipitation retrieved from the 16 SPPs, which revealed the south-north precipitation pattern that is controlled by the moisture-laden south-west trade winds across Nigeria. The mean yearly precipitation from the satellite-based products demonstrates a similar precipitation trend, where a decrease in precipitation corresponds with an increase in latitude. The Guinea/rainforest region experiences an annual mean of about $6000 \mathrm{~mm}$ within the considered period, whereas the annual mean precipitation in the Sahel is about $370 \mathrm{~mm}$.

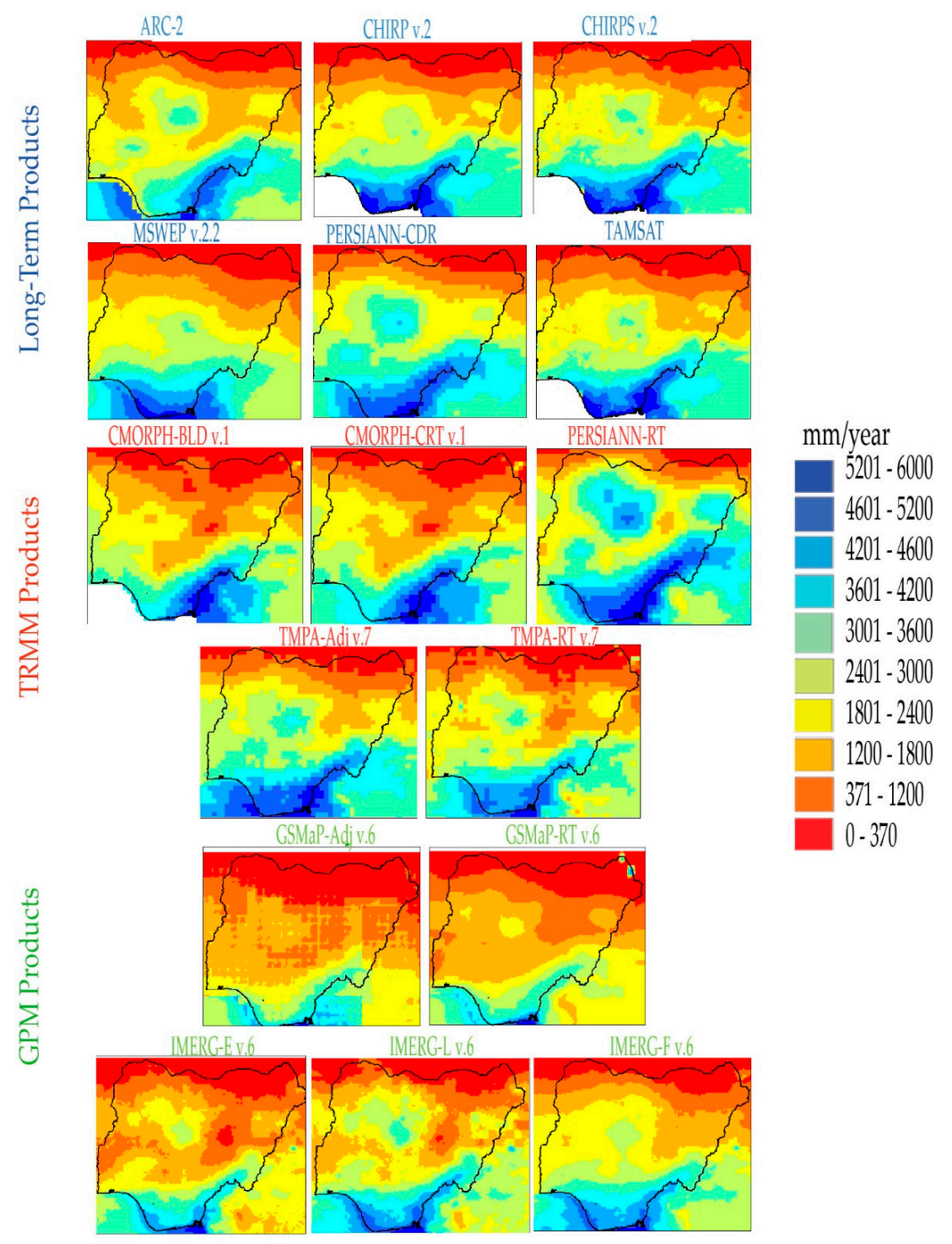

Figure 2. Mean yearly precipitation retrieved from all the satellite-based precipitation products (SPPs) at their original grid size from 2000-2012. 
Table 1. Summary of main characteristics and references of the SPPs. The acronym S, R, G in the data column description stands for satellite, reanalysis, and gauge information; spatial coverage refers to the absolute maximum and minimum latitude with precipitation information, latency refers to the time delay for data availability.

\begin{tabular}{|c|c|c|c|c|c|c|c|c|c|c|}
\hline & Acronym & Name & Period & Data & Spatial Coverage & $\begin{array}{c}\text { Spatial } \\
\text { Resolution }\end{array}$ & $\begin{array}{c}\text { Temporal } \\
\text { Resolution }\end{array}$ & Latency & Link & References \\
\hline 1 & ARC-2 & Africa Rainfall Climatology v.2 & 1983-Present & $\mathrm{S}, \mathrm{G}$ & Africa & $0.1^{\circ} \times 0.1^{\circ}$ & Daily & 2 days & $\begin{array}{l}\text { ftp://ftp.cpc.ncep.noaa.gov/fews/ } \\
\text { fewsdata/africa/arc2/ }\end{array}$ & [42] \\
\hline 2 & CHIRP v.2 & Climate Hazards Group InfraRed v.2 & 1981-Present & $S, R$ & $50^{\circ} \mathrm{N} \times 50^{\circ} \mathrm{S}$ & $0.05^{\circ}$ & Daily & 2 days & $\begin{array}{l}\text { ftp://ftp.chg.ucsb.edu/pub/org/ } \\
\text { chg/products/ }\end{array}$ & [53] \\
\hline 3 & CHIRPS v.2 & $\begin{array}{l}\text { Climate Hazards Group Infrared v.2 } \\
\text { with Station }\end{array}$ & 1981-Present & $S, R, G$ & $50^{\circ} \times 50^{\circ}$ & & Daily & 1 month & $\begin{array}{l}\text { ftp://ftp.chg.ucsb.edu/pub/org/ } \\
\text { chg/products/ }\end{array}$ & [53] \\
\hline 4 & MSWEP v.2.2 & $\begin{array}{l}\text { Multi-Source Weighted Ensemble } \\
\text { Precipitation v.2.2 }\end{array}$ & 1979-Present & $S, R, G$ & Global & $0.1^{\circ}$ & 3 hourly & A few months & $\begin{array}{l}\text { http://www.gloh2o.org/(Personal } \\
\text { communication) }\end{array}$ & [54] \\
\hline 5 & PERSIANN-CDR & $\begin{array}{l}\text { Precipitation Estimates from } \\
\text { Remotely Sensed Information using } \\
\text { Artificial Neural Network and } \\
\text { Climate Data Record }\end{array}$ & 1983-Present & $\mathrm{s}, \mathrm{G}$ & $60^{\circ} \mathrm{N}-60^{\circ} \mathrm{S}$ & $0.25^{\circ}$ & Daily & 3 months & https://chrsdata.eng.uci.edu/ & [55] \\
\hline 6 & PERSIANN-RT & $\begin{array}{l}\text { Precipitation Estimates from } \\
\text { Remotely Sensed Information using } \\
\text { Artificial Neural Network } \\
\text { (Real-Time) }\end{array}$ & 2003-Present & $\mathrm{s}$ & $60^{\circ} \mathrm{N}-60^{\circ} \mathrm{S}$ & $0.25^{\circ}$ & 1 hourly & 2 days & https://chrsdata.eng.uci.edu/ & {$[17,56]$} \\
\hline 7 & TAMSAT v.3 & $\begin{array}{l}\text { Tropical Applications of } \\
\text { Meteorology using Satellite and } \\
\text { Ground-Based Observations v.3 }\end{array}$ & 1983-2018 & $\mathrm{S}, \mathrm{G}$ & Africa & $0.0375^{\circ}$ & Daily & 3 days & https://www.tamsat.org.uk/about & {$[57,58]$} \\
\hline 8 & CMORPH-BLD v.1 & $\begin{array}{l}\text { Climate Prediction Center } \\
\text { MORPHing (Satellite-Gauge } \\
\text { Merged) v.1 }\end{array}$ & 2002-Present & $\mathrm{S}, \mathrm{G}$ & $60^{\circ} \mathrm{N}-60^{\circ} \mathrm{S}$ & $0.25^{\circ}$ & Daily & 10 months & $\begin{array}{l}\text { ftp://ftp.cpc.ncep.noaa.gov/precip/ } \\
\text { CMORPH_V1.0/ }\end{array}$ & [59] \\
\hline 9 & CMORPH-CRT v.1 & $\begin{array}{c}\text { Climate Prediction Center } \\
\text { MORPHing (Bias Corrected) v.1 }\end{array}$ & 2002-Present & $\mathrm{S}, \mathrm{G}$ & $60^{\circ} \mathrm{N}-60^{\circ} \mathrm{S}$ & $0.25^{\circ}$ & Daily & 6 months & $\begin{array}{c}\text { ftp://ftp.cpc.ncep.noaa.gov/precip/ } \\
\text { CMORPH_V1.0/ }\end{array}$ & [59] \\
\hline 10 & TMPA-Adj v.7 & $\begin{array}{l}\text { TRMM Multi-Satellite Precipitation } \\
\text { Analysis Adjusted v.7 }\end{array}$ & 1998-Present & $\mathrm{S}, \mathrm{G}$ & $50^{\circ} \mathrm{N}-50^{\circ} \mathrm{S}$ & $0.25^{\circ}$ & Daily & 3 months & https://earthdata.nasa.gov/ & [15] \\
\hline 11 & TMPA-RT v.7 & $\begin{array}{l}\text { TRMM Multi-Satellite Precipitation } \\
\text { Analysis Real-Time v.7 }\end{array}$ & 2000-Present & $\mathrm{s}$ & $60^{\circ} \mathrm{N}-60^{\circ} \mathrm{S}$ & $0.25^{\circ} \times 0.25^{\circ}$ & Daily & 1 day & https://mirador.gsfc.nasa.gov/ & [15] \\
\hline 12 & GSMaP-Adj v.6 & $\begin{array}{c}\text { Global Satellite Mapping of } \\
\text { Precipitation Standard Adjusted v.6 }\end{array}$ & 2002-2012 & $\mathrm{S}, \mathrm{G}$ & $60^{\circ} \mathrm{N}-60^{\circ} \mathrm{S}$ & $0.1^{\circ}$ & Hourly & 3 days & $\begin{array}{c}\text { ftp: } \\
\text { //hokusai.eorc.jaxa.jp/standard/v6/ }\end{array}$ & {$[60,61]$} \\
\hline 13 & GSMaP-RT v.6 & $\begin{array}{l}\text { Global Satellite Mapping of } \\
\text { Precipitation Standard v.6 }\end{array}$ & 2002-2012 & $\mathrm{s}$ & $60^{\circ} \mathrm{N}-60^{\circ} \mathrm{S}$ & $0.1^{\circ}$ & Hourly & 3 days & $\begin{array}{c}\text { ftp: } \\
\text { //hokusai.eorc.jaxa.jp/standard/v6/ }\end{array}$ & {$[61,62]$} \\
\hline 14 & IMERG-E v.6 & $\begin{array}{l}\text { Integrated Multi-Satellite Retrievals } \\
\text { for GPM Early Run }\end{array}$ & 2000-Present & $\mathrm{s}$ & $60^{\circ} \mathrm{N}-60^{\circ} \mathrm{S}$ & $0.1^{\circ} \times 0.1^{\circ}$ & $30 \mathrm{~min}$ & $4 \mathrm{~h}$ & http://disc.sci.gsfc.nasa.gov/ & [62] \\
\hline 15 & IMERG-F v.6 & $\begin{array}{l}\text { Integrated Multi-Satellite Retrievals } \\
\text { for GPM Final Run }\end{array}$ & 2000-Present & $\mathrm{s}$ & $60^{\circ} \mathrm{N}-60^{\circ} \mathrm{S}$ & $0.1^{\circ} \times 0.1^{\circ}$ & $30 \mathrm{~min}$ & 3 months & http://disc.sci.gsfc.nasa.gov/ & [62] \\
\hline 16 & IMERG-L v.6 & $\begin{array}{l}\text { Integrated Multi-Satellite Retrievals } \\
\text { for GPM Late Run }\end{array}$ & 2000-Present & $\mathrm{S}, \mathrm{G}$ & $60^{\circ} \mathrm{N}-60^{\circ} \mathrm{S}$ & $0.1^{\circ} \times 0.1^{\circ}$ & $30 \mathrm{~min}$ & $12 \mathrm{~h}$ & http://disc.sci.gsfc.nasa.gov/ & [62] \\
\hline
\end{tabular}




\section{Methods}

\subsection{Database Pre-Processing}

The datasets were aggregated into a monthly dataset to match the rain gauge data and resampled to the $0.1^{\circ}$ grid cell size to enable consistent comparison between all SPPs. The bilinear average (interpolation) is used for SPPs with grid cell size $<0.1^{\circ}\left(>0.1^{\circ}\right)[44,63]$.

\subsection{SPP Assessment}

The Kling-Gupta efficiency (KGE) was used to compare the SPPs with rain gauge measurements. KGE is an objective function introduced by Gupta [64], that combines the correlation coefficient $(\mathrm{r})$, bias $(\beta)$, and the ratio of variability $(\gamma)$. The KGE function was necessary since water resource management requires a reliable representation of precipitation temporal dynamics as measured by the correlation coefficient $(\mathrm{r})$ and volume as explained by bias $(\beta)$ and variability $(\gamma)$. Both aspects (temporal dynamics and volume) might be relevant for different purposes, as potential readers might be interested in an efficient representation of one or other element in the function of the foreseen utilisation of SPPs. The equations are expressed as follows:

$$
\mathrm{KGE}=1-\sqrt{(\mathrm{r}-1)^{2}+(\beta-1)^{2}+(\gamma-1)^{2}}
$$

where (r) denotes the ratio between the observation and the modelled correlation coefficients, $\beta$ is the ratio between the observed and the modelled means, and $(\gamma)$ is the ratio of the estimated and observed coefficients of variation.

$$
\begin{gathered}
\mathrm{r}=\frac{1}{\mathrm{n}} \sum_{1}^{\mathrm{n}} \frac{\left(\mathrm{o}_{\mathrm{n}}-\mu_{\mathrm{o}}\right) *\left(\mathrm{~s}_{\mathrm{n}}-\mu_{\mathrm{s}}\right)}{\sigma_{\mathrm{o}} * \sigma_{\mathrm{s}}} \\
\beta=\frac{\mu_{\mathrm{s}}}{\mu_{\mathrm{o}}} \\
\gamma=\frac{\sigma_{\mathrm{s}} / \mu_{\mathrm{s}}}{\sigma_{\mathrm{o}} / \mu_{\mathrm{o}}}
\end{gathered}
$$

where $\mu$ and $\sigma$ are the distribution mean and standard deviation, respectively; $\mathrm{s}$ and o indicate the estimate and the reference, respectively.

From Equation (1), r, $\beta$, and $\mathrm{Vr}$ analyses of the products were carried out for all the months within the period 2000-2012, as well as the dry and wet seasons. The values of the involved coefficients in KGE, $r, \beta$, and $\gamma$, were computed at each grid cell location to observe the spatial reliability of the SPPs, and their median values were adopted for regional-scale observation.

\section{Results}

\subsection{SPP Reliability on the National Scale}

Monthly and seasonal performances of the SPPs in terms of KGE, correlation coefficient ( $r$ ), bias ( $\beta$ ), and variability ratio $(\gamma)$ for the 2000-2012 period are expressed in Figure 3.

With a KGE value inferior to 0.4, TMPA-RT v.7 and PERSIANN-RT were unable to represent the regional monthly precipitation. Interestingly, the gauge adjustment applied for TMPA-Adj v.7 drastically increased KGE from <0.4 (TMPA-RT v.7) to 0.81 (TMPA-Adj v.7). Similarly, the gauge-adjusted version of IMERG-F v.6 presented a higher KGE score (0.82) than the only satellite-based version, IMERG-E v.6 (0.69) and IMERG-L v.6 (0.71). Actually, IMERG-F v.6 is the second most reliable SPP just after MSWEP v.2.2, which presents the highest KGE score (0.83).

MSWEP v.2.2, CHIRPS v.2, and PERSIANN-CDR precipitation estimates are derived from several gridded precipitation datasets (P-datasets) from satellite, reanalysis, and gauges. CHIRPS v.2 and PERSIANN-CDR include only one gauge-based P-dataset each (CHPclim and GPCP, respectively), 
while MSWEP v.2.2 includes three gauge-based P-datasets (GPCP, GPCC, WorldClim). They also include fewer satellite- and reanalysis-based P-datasets than MSWEP v.2.2. This difference in terms of input numbers can partially explain the better reliability of MSWEP v.2.2 in comparison to CHIRPS v.2, PERSIANN-CDR, and all the considered SPPs in this study. Notably, MSWEP v.2.2 and CHIRPS v.2 use precipitation estimates from some of the considered SPPs as input data (GSMaP-RT v.6 and TMPA-RT v.7 for MSWEP v.2.2 and TMPA-Adj v.7 for CHIRPS v.2). Thus, as "level-2" versions of these specific SPPs, they provide more reliable precipitation estimates. Interestingly, even if IMERG-F v.6 does not consider such a multisource approach, it still offered precipitation estimates almost as reliable as MSWEP v.2.2. Therefore, the IMERG technique is up-and-coming and recommended in future multi-source precipitation datasets.

Most of the P-datasets were well correlated to the reference $(>0.8)$ except PERSIANN-RT and TMPA-RT v.7 (0.79 and 0.62, respectively). The gauge-adjusted versions presented a higher correlation than their non-adjusted version, as observed for IMERG-F v.6 (TMPA-Adj v.7) when compared to IMERG-E and -L v.6 (TMPA-RT v.7). Interestingly, IMERG-F v.6 presents a slightly superior correlation value compared to MSWEP v.2.2, which both offer the highest score.

Non-adjusted SPPs, PERSIANN-RT, TMPA-RT v.7, and IMERG-E and -L v.6 overestimate precipitation amount. The gauge-based adjustment efficiently removed the bias, as observed with a bias value close to 1 for TMPA-Adj v.7 and IMERG-F v.6. In a general way, all SPPs using gauge-based datasets present reasonable bias values $(0.85>$ and $<1.15)$. However, the gauge-based adjustment in GSMaP-Adj v.6 introduced a lower bias (0.85) when compared to the non-adjusted version of GSMaP-RT v.6 (0.91). The bias values, as seen here, confirmed previous studies which highlighted deficiencies in the adjustment of GSMaP SPPs across Africa, such as Satgé et al. (2020) [63], and Beck et al. (2019) [65].

Regarding the Vr, all SPPs presented a Vr close to one except for PERSIANN-RT and TMPA-RT v.7, which underestimated precipitation variability $(\mathrm{Vr}<0.85)$. However, these SPPs are also the less efficient ones in terms of KGE, correlation, and bias.

On a seasonal basis, a robust trend was observed for all SPPs, with the highest reliability (as expressed by KGE) during the wet season compared to the dry season. Differences between wet and dry month-based KGE values is essentially linked with significant differences in $r$ values for both seasons. In contrast, similar $\beta$ and $\mathrm{Vr}$ values were observed for both wet and dry months. This seasonal variation is linked to the monthly precipitation total distribution [45]. Across Nigeria, the monthly precipitation totals are well (poorly) distributed between the maximum and minimum values during the dry season (wet season) (Figure 1). This feature tends to increase correlation and therefore the KGE value during the dry season. As this distribution is even better when considering the whole period, the all-month $r$ increases, thereby increasing the KGE. 


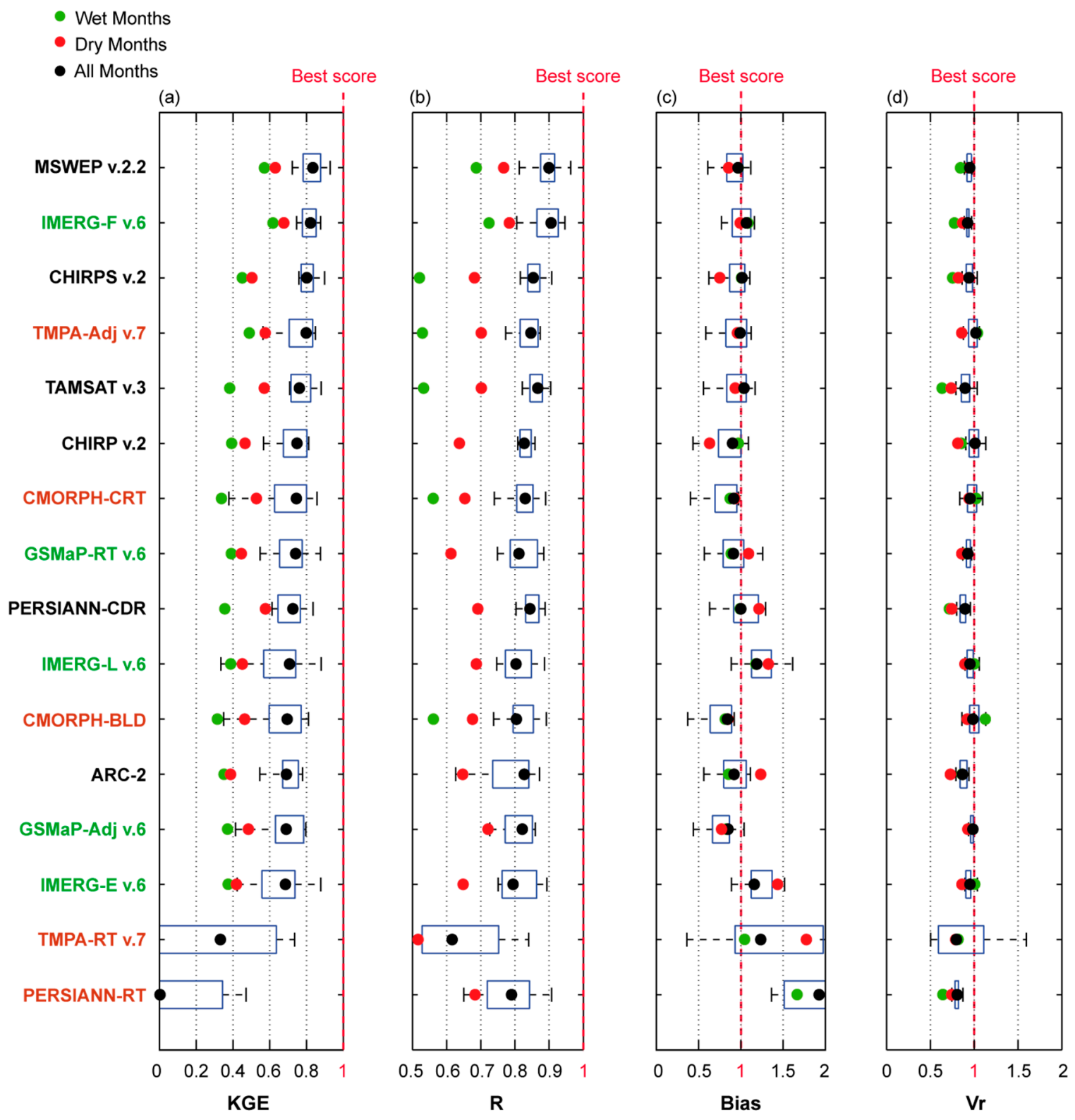

Figure 3. Box plot statistical summary of (a) Kling-Gupta efficiency (KGE), (b) correlation coefficient (r), (c) bias $(\beta)$, and $(\mathbf{d})$ variability ratio $(\mathrm{Vr})$, based on the sixteen SPPs and eleven gauging stations across Nigeria. The performances in terms of KGE, correlation coefficient, bias, and variability ratio of all SPPs across all months are highlighted in black, while their seasonal performances are highlighted in green and red for the rainy and dry seasons, respectively. The SPPs in black represent the long-term group, while the Tropical Rainfall Measuring Mission (TRMM) is in red and the Global Precipitation Mission (GPM) is in green.

\subsection{SPP Reliability for Different Climatic Regions}

In this section, the values of the statistical scores (KGE, $r, \beta$, and $\mathrm{Vr}$ ) calculated at the locations of the gauges and for the three Nigerian climatic regions are presented (Figures 4-7). 


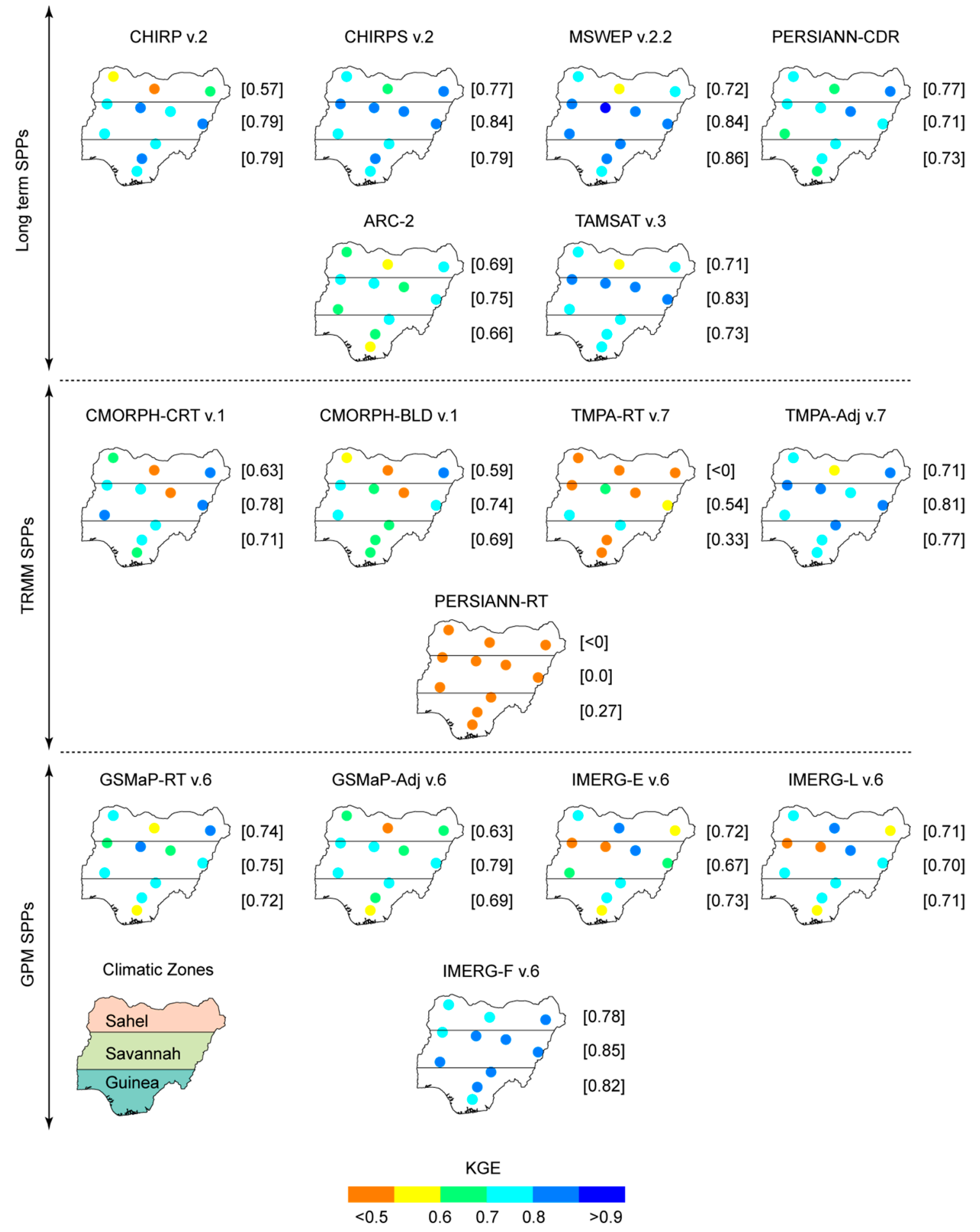

Figure 4. KGE values obtained at the grid cell level of all the SPPs corresponding to gauge stations in the period 2000-2012. The SPPs are grouped according to their respective categories, and the gauges are separated by the country's ecological zones. 

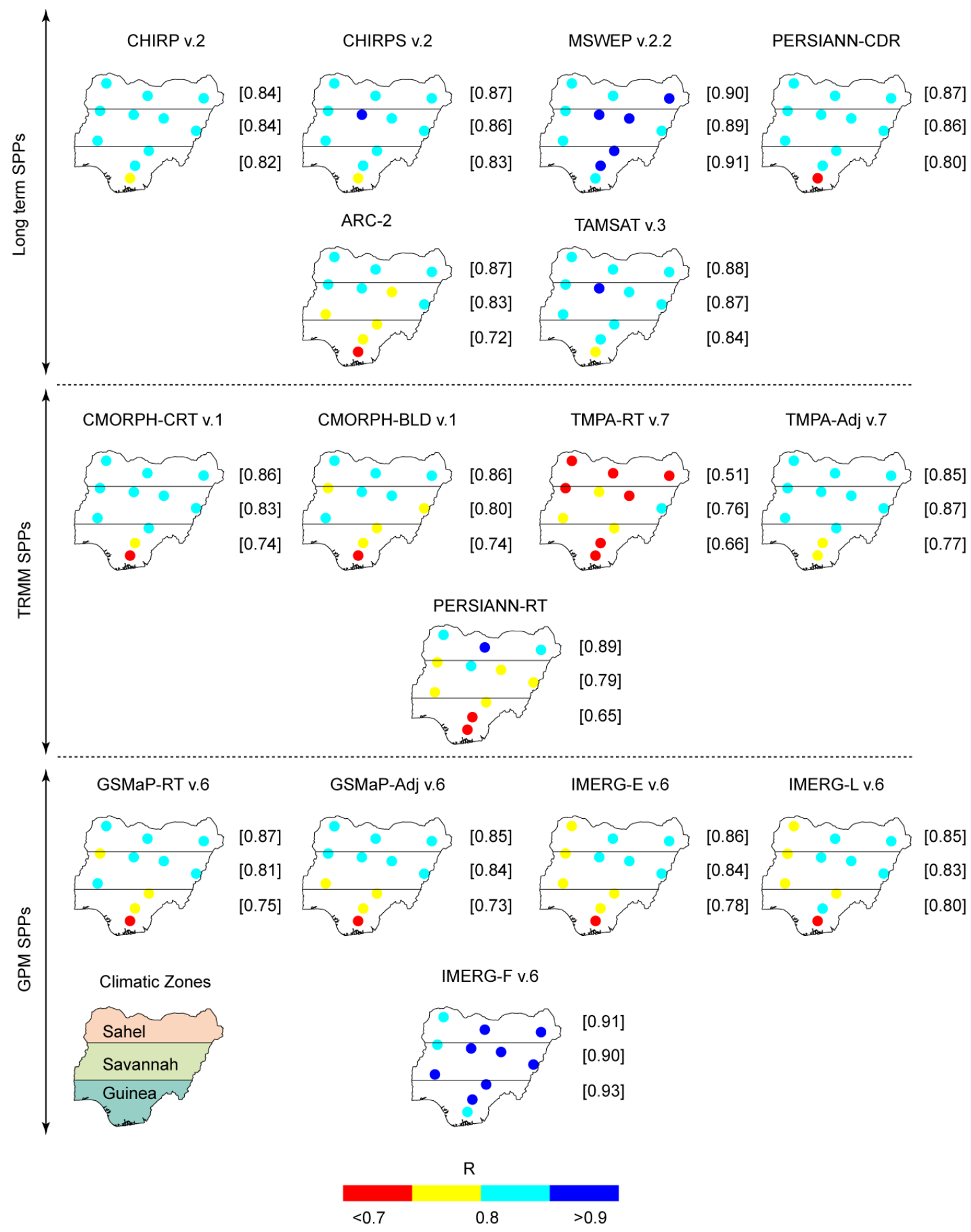

Figure 5. R scores obtained at the grid cell level of all the SPPs corresponding to gauge stations in the period 2000-2012. The SPPs are grouped according to their respective categories, and the gauges are separated by the country's ecological zones. Values in brackets are the average of the scores obtained inside the same ecological zone. 

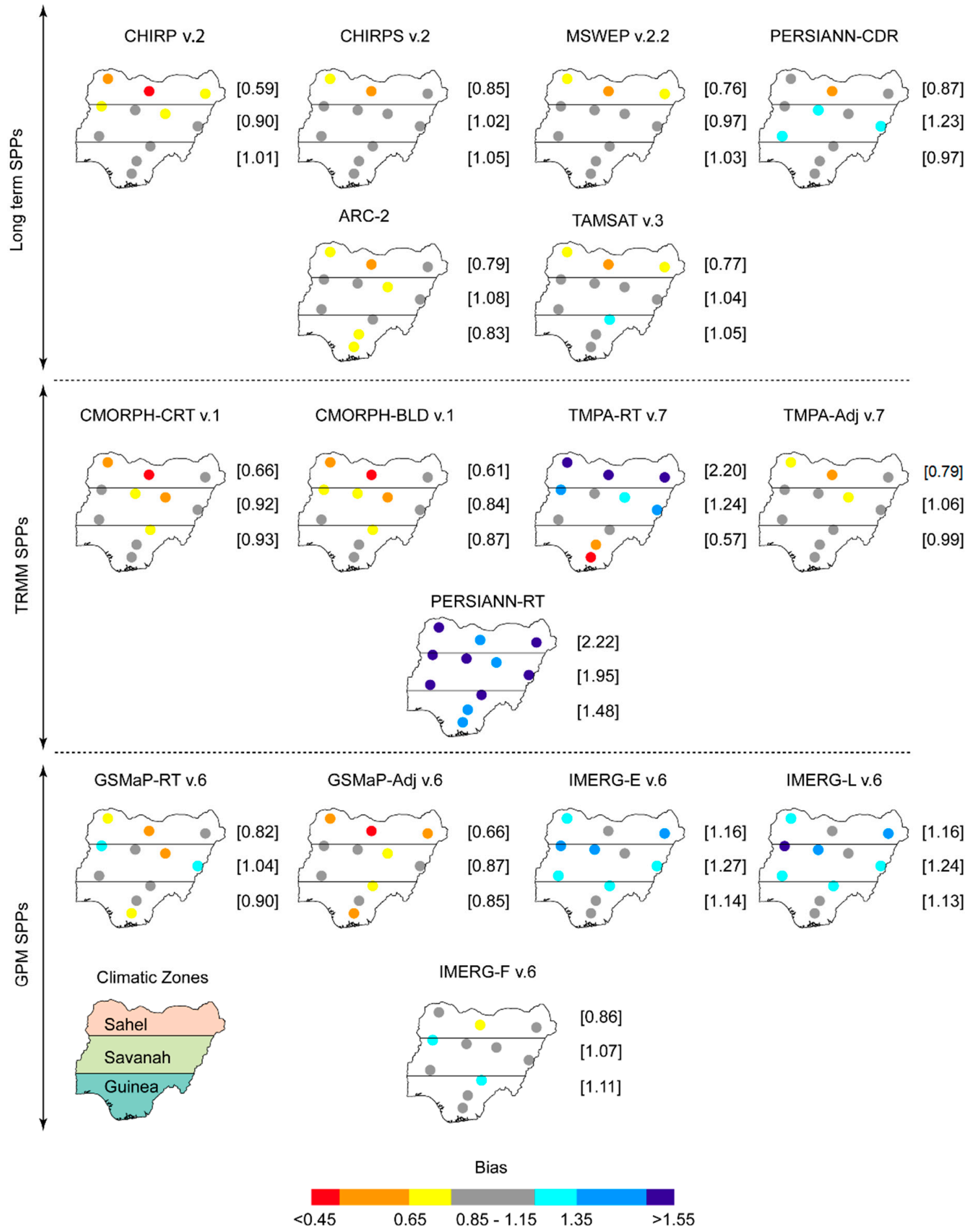

Figure 6. The $\beta$ values obtained at the grid cell level for all SPPs over the 2000-2012 period. The SPPs are grouped according to their respective categories, and the gauges are separated by the country's ecological zones. 


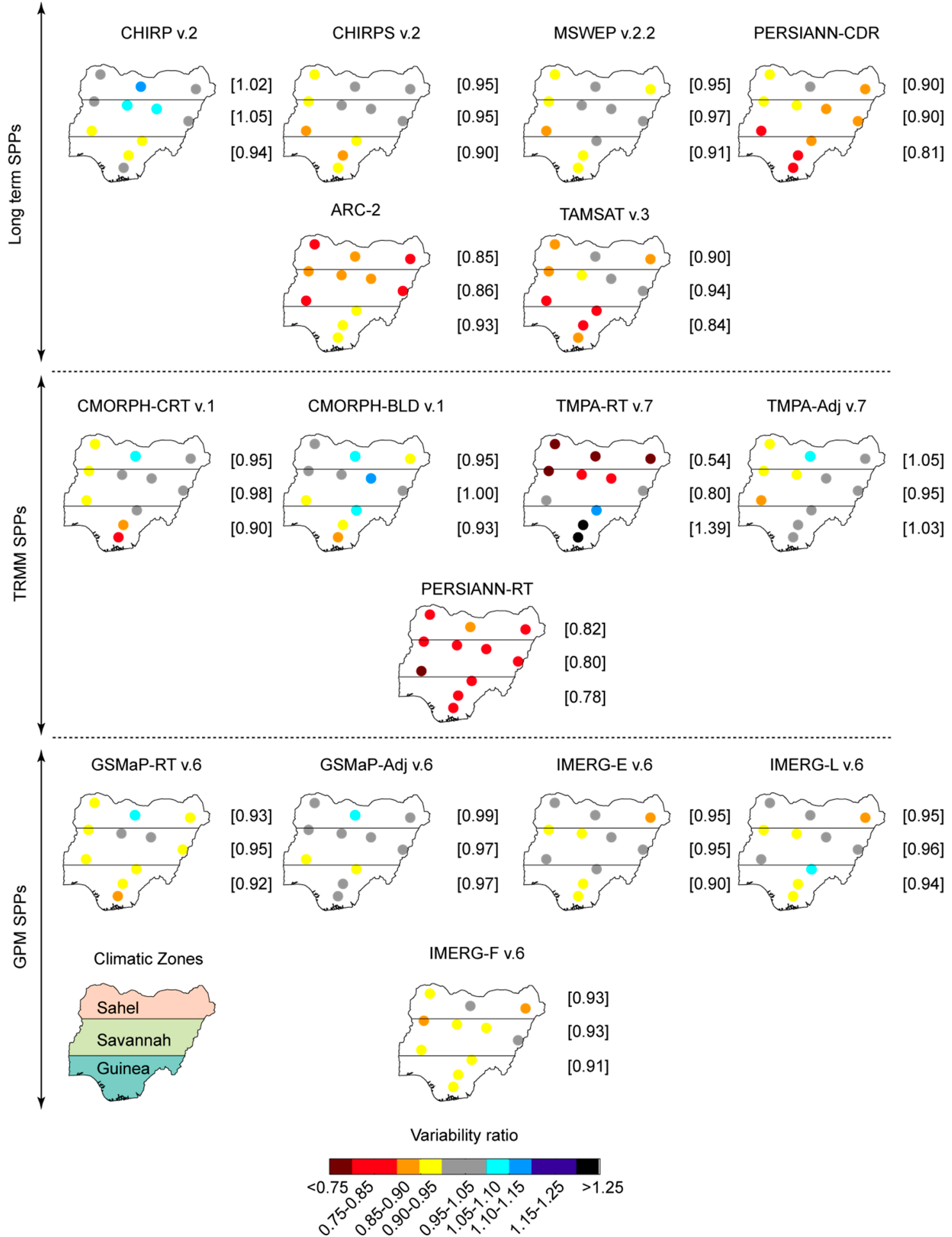

Figure 7. The Vr values obtained at the grid cell level for all SPPs over the 2000-2012 period. The SPPs are grouped according to their respective categories, and the gauges are separated by the country's ecological zones.

The KGE values obtained from all considered SPPs at the eleven gauge locations are reported in Figure 4. The benefits of the gauge adjustment process observed at the regional scale are observed at all gauge locations when considering TMPA-Adj v.7 and IMERG-F v.6 in comparison to TMAP-RT v.7 and IMERG-E and -L v.6, respectively. Regarding GSMaP SPPs, the adjustment is only significant across the Savannah region. 
The most efficient SPP varies according to the considered region. With a KGE of 0.77, 0.77, and 0.78, espectively, PERSIANN-CDR, CHIRPS v.2, and IMERG-F v.6 present the most efficient values across the Sahel region. In contrast, MSWEP v.2.2, CHIRPS v.2, and IMERG-F v.6 showed the highest KGE score over the central Savannah region $(0.84,0.84,0.85)$. Finally, across the southern Guinea region, MSWEP v.2.2 is the most efficient SPP (KGE =0.86).

Generally, all SPPs presented lower KGE scores for the gauges located in the northern Sahel region. Passive and active microwave (PMW) sensors onboard a low Earth-orbital (LEO) satellite are the main input for precipitation estimates for most of the considered SPPs (TMPA, CMORPH, IMERG, GSMaP, CHIRP, and MSWEP v.2.2). The orbital trajectory of the LEO satellite limited the number of overpasses and thus hardly captures short precipitation events which are typical in a semi-arid context, as observed across the Sahel region [66,67]. To fill the gaps, IR sensors on board of geostationary satellite (continuous observation in time) are commonly used to augment the primary input during the second step. Contrarily, PERSIANN-CDR uses IR information as the input of an artificial neural network trained with precipitation estimates obtained by PMW sensors. Using IR data as the main input allows for a continuous observation, which seems adapted to the arid context of the Sahel region. Indeed, PERSIANN-CDR is the SPP providing the highest KGE score for the Sahel region. It is worth mentioning here that TAMSAT v.3 also used IR data as the main input for its precipitation estimates. TAMSAT v.3 used a cloud temperature threshold calibrated in space and time with gauge records. The heterogeneous distribution of the African rain gauges might introduce uncertainty in the threshold value for some regions, as observed across the Sahel region.

As observed for the KGE, the adjusted version of TMPA-Adj v.7 and IMERG-F v. 6 presented higher $r$ values for all regions and considered stations in comparison to TMPA-RT v.7 and IMERG-E and -L v.6, respectively. The adjustment on GSMaP shows more contrast, with a clear improvement (degradation) observable across the Sahel (Guinea) region. Interestingly, except for MSWEP v.2.2 and IMERG-F v.6, which exhibit a higher correlation for all considered grid cells and regions, the SPPs presented lower correlation across the southern Guinea region. The southern part of Nigeria is a naturally cloudy region. The continuous presence of clouds, regardless of a rainy episode, might be challenging for SPP retrieval. On the contrary, the presence of cloud in the northern Savannah and Guinea regions are more related to rainy episodes, which minimizes potential mismatches between rain and no-rain clouds. This difference may partially explain the higher correlation observed from more gauge stations over the Sahel region.

In general, all SPPs underestimated precipitation in the northern Sahel region. As the correlation is generally higher for this region, it seems that the SPPs correctly captured the temporal occurrence of precipitation event but still underestimated the amount. This might come from specific short-term and light precipitation events occurring across the arid region, which is challenging for SPP retrieval methods $[67,68]$. However, it is worth mentioning here that an equivalent bias expressed in $\mathrm{mm}$ equals a different relative bias (Equation (3)) if considering high or low precipitation amounts. Therefore, the same bias (in $\mathrm{mm}$ ) will result in higher relative bias over the Sahel than the Savannah or Guinea regions. The differences could partially explain the higher bias value observed over the Sahel region.

Finally, though that high discrepancy was observed in terms of SPP bias spatial distribution across Nigeria, over the Sahel region, IMERG-F v.6 and PERSIANN-CDR presented bias values closer to 1 ( 0.86 and 0.87 , respectively). Whereas for the Savannah region, CHIRPS v.2 and MSWEP v.2.2 had 1.02 and 0.97, respectively. Finally, across the Guinea region, CHIRP v.2 and TMPA-Adj v.7 provided the less biased precipitation estimates, with a bias of 1.01 and 0.99 , respectively.

Regarding the $\mathrm{Vr}$ values, all SPPs underestimated precipitation variability, particularly PERSIANN-RT and TMPA-RT v.7, and to a lesser extent ARC-2, TAMSAT v.3, and PERSIANN-CDR. The other SPPs presented reasonable Vr values. Interestingly, the gauge-based adjustment led to contradictory results depending on the considered SPPs. Indeed, IMERG-F v.6 had a lower Vr value 
than the non-adjusted version (IMERG-E and -L v.6), whereas both TMPA-Adj v.7 and GSMaP-Adj v.6 have Vr values closer to one compared to their non-adjusted versions (TMPA-RT v.7 and GSMaP-RT v.6).

As a general conclusion on gauge-based adjustment, despite an overall increase in KGE for TMPA and IMERG SPPs, the benefit shows more contrast when considering the KGE variables ( $r, \beta$, and $\mathrm{Vr}$ ) across the main Nigerian climatic regions (Sahel, Savannah, and Guinea). While all KGE variables (r, Bias and Vr) increased for TMPA across all climatic regions (Sahel, Savannah, and Guinea), a slight decrease was observed in terms of $\mathrm{Vr}$ for IMERG and all climatic regions. More interestingly, GSMaP Vr improved for all region, whereas $\beta$ (r) increased (decreased) for all regions (Savannah). Therefore, the adjustment process of GSMaP v.6 and IMERG-F v.6 should be optimised to avoid compromise in terms of precipitation feature optimisation (i.e., $\beta, r, \mathrm{Vr}$ ).

\section{Discussion}

\subsection{Long-Term SPPs for Precipitation Trend Analysis}

This study aims to validate the usability and potency of long-term, TRMM, and GPM products for Nigeria using thirteen years of gauge observation data. However, the SPP reliability may exhibit temporal variation due to (i) different combinations of sensors over time, related to both ageing and newly released sensors, (ii) occasional technical issues, and (iii) variation in the available gauges (number and location) used to adjust some SPPs [68]. Variation in SPP reliability over time can influence SPP-based precipitation trend analysis. It is, therefore, crucial to report on SPP reliability over time. In this context, Figure 8 showed the KGE performance of the considered long-term SPPs (ARC-2, CHIRP v.2, CHIRPS v.2, MSWEP v.2.2, PERSIANN-CDR, and TAMSAT v.3) before 2000 (1985-1999) and after 2000 (2000-2012). Before 2000, the KGE is slightly better than after 2000 for all SPPs (except ARC-2). The highest difference between the KGE values obtained before and after 2000 was observed from CHIRP v.2 and CHIRPS v.2 (Figure 8). A similar observation was made for CHIRPS v.2 over Nepal and was attributed to a decrease in available gauges for the adjustment process [69]. Similarly, the trend (KGE before 2000 higher than KGE after 2000) observed for MSWEP v.2.2, PERSIANN-CDR, and TAMSAT v.3 could be related to the gauge-based precipitation dataset (used in these particular SPPs) variation in terms of the number of gauges. In this context, TAMSAT v.3 uses consistent gauge-based information in space and time rather than continuously updated information to avoid adding any space or time discrepancy into the gauge network [70]. Still, the KGE varies slightly in time, as other factors, such as ageing sensors and different sensor combinations, can influence SPP reliability over time.

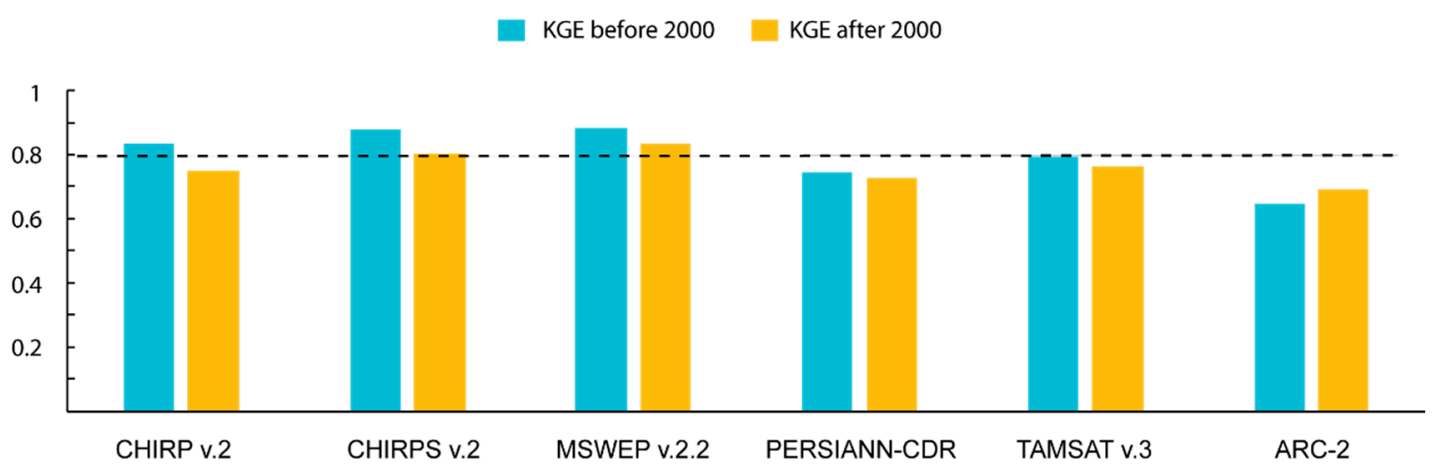

Figure 8. Median KGE values obtained from all the grid cell levels before and after 2000.

Finally, with a median KGE value higher than 0.8 before and after 2000, MSWEP v.2.2 appears to be the best option for long-term precipitation needs over Nigeria. This is in line with the previous finding over the South American Andean Plateau [68]. 


\subsection{Enhancement from TRMM to GPM SPPS}

The GPM came into existence to ensure the continuity of the TRMM. The expectations were high for GPM due to an increase in spatial $\left(0.1^{\circ}\right)$ and temporal $(30 \mathrm{~min})$ resolution. GPM SPPs (IMERG and GSMaP) are expected to provide an estimate of precipitation that is at least as accurate as that produced by the TRMM SPPs (TMPA-Adj and -RT v.7, CMORPH-CRT and -BLD v.1, PERSIANN-RT).

Figure 9 shows the difference in KGE values obtained at each grid cell between IMERG and TMPA SPPs. IMERG and TMPA datasets were compared, taking into account their available time latency. Therefore, IMERG-E and -L v.6 (time latency of 4 and $12 \mathrm{~h}$, respectively) were compared to TMPA-RT v.7 (1 day latency) (Figure 9b,c), whereas IMERG-F v.6 (latency of 3 months) was compared to TMPA-Adj v.7 (3 months' latency) (Figure 9a). Finally, IMERG-E and -L v.6 were also compared (Figure 9d). GSMaP-RT v.6, GSMaP-Adj v.6, CMOPRH-CRT v.1, CMORPH-BLD v.1, and PERSIANN-RT were not considered for comparison because their overall reliability is lower than IMERG and TMPA datasets (Figure 4). IMERG-F v.6 reaches higher KGE values than TMPA-Adj v.7 at nine out of 11 grid cell locations (Figure 9a). The same was observed when comparing IMERG-E v.6 and -L v.6 to TMPA-RT v.7 (Figure 9b,c). These results highlight a significant enhancement in precipitation estimates from TRMM to GPM SPPs. This finding is consistent with previous results reported in Bolivia [30], Brazil [37,38], and Pakistan [26]. Finally, IMERG-E v.6 and IMERG-F v.6 show a strong agreement with an absolute difference inferior to 0.05 at 10 out of 12 gauge locations (Figure 10d). Therefore, for real-time requirements, IMERG-E v.6 could be used instead of IMERG-L v.6 to obtain faster access to precipitation estimates across Nigeria ( $4 \mathrm{~h}$ instead of $12 \mathrm{~h}$ ).
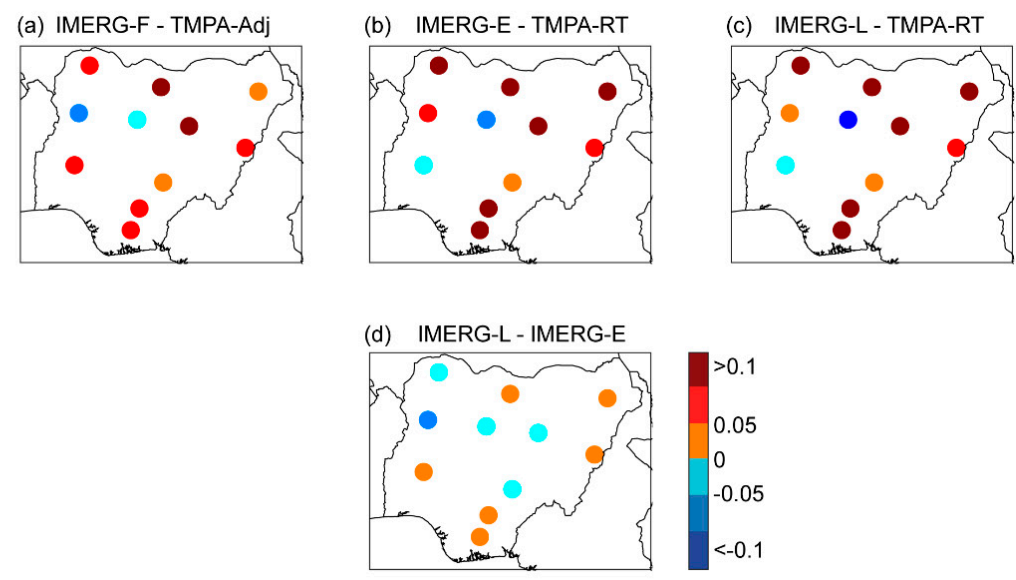

Figure 9. Comparative display of TRMM and GPM product performance at the gauge locations by comparing TRMM-TMPA vs. GPM-IMERG. (a) The performance of IMERG-F v.6 with TMPA-Adj v.7, (b) IMERG-E v.6 with TMPA-RT V.7, (c) IMERG-L v.6 with TMPA-RT v.7, (d) IMERG-L v.6 with IMERG-E v.6 at rain gauge points. 
(a)

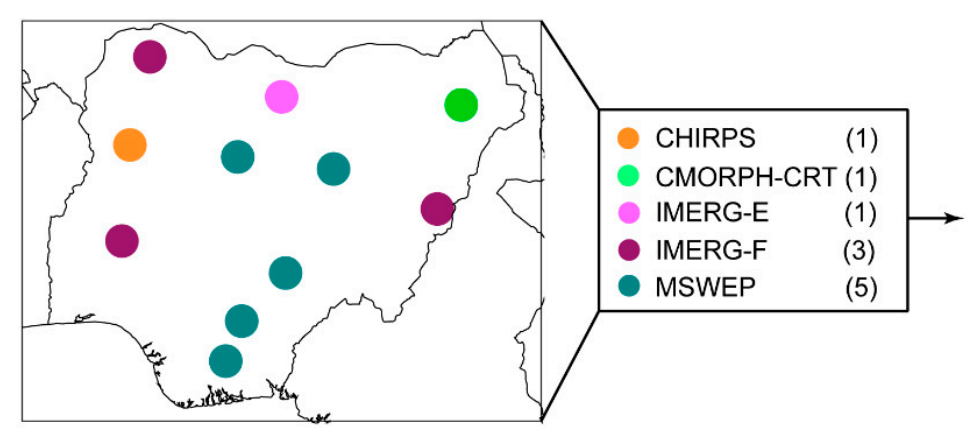

(b)

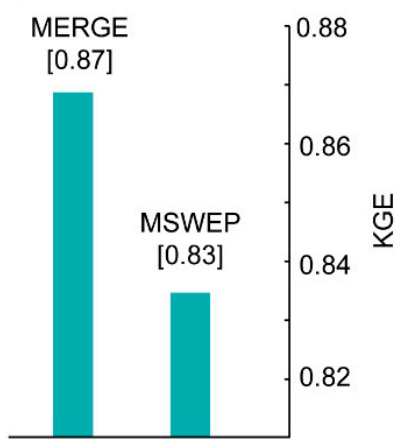

Figure 10. (a) Merging of the best product to each location's result revealed that MSWEP performed better in 5 out of 11 locations, (b) cumulative overall KGE score of MSWEP v.2.2 against the best performing products in other location.

\subsection{Towards an Enhanced Precipitation Dataset over Nigeria}

As observed in Figures 5-8, the SPP reliability varies in space, indicating that different SPPs should be considered depending on the region of interest within Nigeria. In this context, Figure 10 showed the SPPs with the highest KGE value at each considered grid cell. MSWEP v.2.2 showed the most robust performance in five gauge stations located in the central Nigeria region. IMERG-F v.6 reaches the highest KGE value at three grid cell locations, while CHIRPS v.2, IMERG-E v.6, and CMORPH-CRT v.1 are the best performers at a single grid location. To take advantage of all available SPPs, merging all SPPs to produce an enhanced precipitation dataset over the region should be a good option as shown in Figure 10. The potential benefit of such an improved precipitation dataset can be highlighted by the median KGE value of the most efficient SPP at each of the considered grid cell locations (Figure 10b). The enhanced precipitation dataset reached a KGE value higher (0.87) than the most efficient SPP (MSWEP V.2.2, KGE = 0.83). Previous studies have reported on different merging approaches to retrieve a more realistic precipitation dataset from various SPPs over Pakistan [71,72], Tibet [73], and different tropical complex terrains [74]. This method should be used as a guideline for Nigeria.

It is worth mentioning here that Figure 10 presents the best SPP in term of KGE. However, as shown in the results section, the most efficient SPP changes according to the considered variables (i.e., KGE, $r, \beta$, and Vr). For instance, the most efficient SPPs in term of bias are IMERG-F v.6 and PERSIANN-CDR across the Sahel region, CHIRPS v.2 and MSWEP v.2.2 across the Savannah region, and CHIRP v.2 and TMPA-Adj v.7 across the Guinea region. Therefore, interested users should select different SPPs in agreement with the foreseen use.

\section{Conclusions}

In this study, the reliability of sixteen satellite precipitation estimates was evaluated for Nigeria using Kling-Gupta efficiency scores at eleven gauge locations across Nigeria for the 2000-2012 period. Despite the scarcity of ground reference points, some consistent features emerged from the analysis:

- When considering the long-term SPPs, MSWEP v.2.2 and CHIRPS v.2 provide the most reliable precipitation estimates over Nigeria.

- When considering TRMM-based SPPs, TMPA-Adj v.7 outperformed CMORPH-CRT v.1 and -BLD v.1, while TMPA-RT v.7 outperformed PERSIANN-RT

- When considering the GPM-based SPPs, the IMERG-F v.6 precipitation estimate is more realistic than that of GSMaP-Adj v.6, while IMERG-L v.6 and GSMaP-RT v.6, which are without gauge adjustment, produced a similar performance.

- Overall, the transition from TRMM to GPM constitutes an apparent enhancement of precipitation estimates over Nigeria with GPM-based SPPs providing more realistic monthly precipitation estimates than TRMM-based SPPs. 
- IMERG-F v.6, which only uses satellite- and gauge-based precipitation estimates, provides precipitation information as accurate as that of MSWEP v.2.2, which combines data from several sources (satellite, gauge, and reanalysis). The use of IMERG-F v.6 in such a multi-source approach should provide improved precipitation estimates.

- SPP accuracy is region dependent, with variable ranking in SPP performance according to the considered region. In this context, the development of an SPP merging approach is suggested to improve the precipitation representation over Nigeria.

As a general conclusion, with 40 (20) years of precipitation observations, MSWEP v.2.2 (IMERG-F v.6) is the best SPP option to consider when focusing on precipitation trends, as well as support for water resource management.

Author Contributions: Conceived the experiments and provided data: P.N.N. and F.S. Proposed the method: F.S., M.-P.B., and S.E.Y. Processed/analysed the data: F.S. and P.N.N. Contributed to the discussion/revision: S.E.Y., F.S. and M.-P.B. Wrote the original draft: P.N.N. Performed English editing and global presentation of the paper: S.E.Y., F.S., M.-P.B. and S.P. All authors have read and agreed to the published version of the manuscript.

Funding: This study is part of P.N.N.'s thesis, which is being carried out at the University of Perpignan. The study is being funded by the Petroleum Technology Development Fund (PTDF), Nigeria. The article processing charges (ACP) were supported by UMR Espace-Dev.

Acknowledgments: This work was supported by the Petroleum Technology Development Fund (PTDF), Nigeria, IMAGES UMR Espace-Dev, IRD France, and the Doctoral School 305 of the University of Perpignan Via Domitia.

Conflicts of Interest: The authors declare no conflict of interest.

\section{Glossary}

$\begin{array}{ll}\text { ARC-2 } & \text { African Rainfall Climatology. } \\ \text { CHIRP } & \text { Climate Hazards Group Infrared Precipitation. } \\ \text { CHIRPS V.2 } & \text { Climate Hazards Group Infrared Precipitation with Stations. } \\ \text { CMORPH-BLD } & \text { Climate Prediction Centre Morphing Technique (Bias Corrected). } \\ \text { CMORPH-CRT V.1 } & \text { Climate Prediction Centre Morphing Technique. } \\ \text { GSMaP-RT } & \text { Global Satellite Mapping of Precipitation. } \\ \text { GSMaP-Adj } & \text { Global Satellite Mapping of Precipitation (Adjusted). } \\ \text { IMERG-E } & \text { Integrated Multi-Satellite Retrievals for GPM Early Run. } \\ \text { IMERG-F } & \text { Integrated Multi-Satellite Retrievals for GPM Final Run. } \\ \text { IMERG-L } & \text { Integrated Multi-Satellite Retrievals for GPM Later Run. } \\ \text { MSWEP } & \text { Multi-Source Weighted-Ensemble Precipitation. } \\ \text { PERSIANN-RT } & \text { Precipitation Estimation from Remotely Sensed Information using Artificial Neural Networks. } \\ \text { PERSIANN-CDR } & \text { Precipitation Estimation from Remotely Sensed Information using Artificial Neural Networks } \\ \text { TAMSAT } & \text { Climate Data Record. } \\ \text { TMPA-Adj } & \text { Tropical Applications of Meteorology using Satellite Data and Ground-Based Observations. } \\ \text { TMPA-RT } & \text { TRMM Multi-Satellite Precipitation Analysis. } \\ & \text { TRMM Multi-Satellite Precipitation Analysis. }\end{array}$

\section{References}

1. Ayehu, G.T.; Tadesse, T.; Gessesse, B.; Dinku, T. Validation of new satellite rainfall products over the Upper Blue Nile Basin, Ethiopia. Atmos. Meas. Tech. 2018, 11, 1921-1936. [CrossRef]

2. Liu, J.; Zhou, Z.; Yan, Z.; Gong, J.; Jia, Y.; Xu, C.-Y.; Wang, H. A new approach to separating the impacts of climate change and multiple human activities on water cycle processes based on a distributed hydrological model. J. Hydrol. 2019, 578, 124096. [CrossRef]

3. Asfaw, A.; Simane, B.; Hassen, A.; Bantider, A. Variability and time series trend analysis of rainfall and temperature in northcentral Ethiopia: A case study in Woleka sub-basin. Weather Clim. Extrem. 2018, 19, $29-41$. [CrossRef]

4. Taxak, A.K.; Murumkar, A.; Arya, D. Long term spatial and temporal rainfall trends and homogeneity analysis in Wainganga basin, Central India. Weather Clim. Extrem. 2014, 4, 50-61. [CrossRef] 
5. Duan, Z.; Tuo, Y.; Liu, J.; Gao, H.; Song, X.; Zhang, Z.; Yang, L.; Mekonnen, D.F. Hydrological evaluation of open-access precipitation and air temperature datasets using SWAT in a poorly gauged basin in Ethiopia. J. Hydrol. 2019, 569, 612-626. [CrossRef]

6. Fenta, A.A.; Yasuda, H.; Shimizu, K.; Ibaraki, Y.; Haregeweyn, N.; Kawai, T.; Belay, A.S.; Sultan, D.; Ebabu, K. Evaluation of satellite rainfall estimates over the Lake Tana basin at the source region of the Blue Nile River. Atmos. Res. 2018, 212, 43-53. [CrossRef]

7. Karimi, P.; Bastiaanssen, W.G.M. Spatial evapotranspiration, rainfall and land use data in water accounting-Part 1: Review of the accuracy of the remote sensing data. Hydrol. Earth Syst. Sci. 2015, 19, 507-532. [CrossRef]

8. Maggioni, V.; Meyers, P.C.; Robinson, M.D. A Review of Merged High-Resolution Satellite Precipitation Product Accuracy during the Tropical Rainfall Measuring Mission (TRMM) Era. J. Hydrometeorol. 2016, 17, 1101-1117. [CrossRef]

9. Trejo, F.J.P.; Barbosa, H.A.; Peñaloza-Murillo, M.A.; Moreno, M.A.; Farías, A. Intercomparison of improved satellite rainfall estimation with CHIRPS gridded product and rain gauge data over Venezuela. Atmósfera 2016, 29, 323-342. [CrossRef]

10. Dinku, T.; Funk, C.; Peterson, P.; Maidment, R.; Tadesse, T.; Gadain, H.; Ceccato, P. Validation of the CHIRPS satellite rainfall estimates over eastern Africa. Q. J. R. Meteorol. Soc. 2018, 144, 292-312. [CrossRef]

11. Harrison, L.; Funk, C.; Peterson, P. Identifying changing precipitation extremes in Sub-Saharan Africa with gauge and satellite products. Environ. Res. Lett. 2019, 14, 085007. [CrossRef]

12. Jiang, L.; Bauer-Gottwein, P. How do GPM IMERG precipitation estimates perform as hydrological model forcing? Evaluation for 300 catchments across Mainland China. J. Hydrol. 2019, 572, 486-500. [CrossRef]

13. Kidd, C.; Tan, J.; Kirstetter, P.; Petersen, W.A. Validation of the Version 05 Level 2 precipitation products from the GPM Core Observatory and constellation satellite sensors. Q. J. R. Meteorol. Soc. 2018, 144, 313-328. [CrossRef]

14. Huffman, G.J.; Bolvin, D.T.; Nelkin, E.J.; Wolff, D.B.; Adler, R.F.; Gu, G.; Hong, Y.; Bowman, K.P.; Stocker, E.F. The TRMM Multisatellite Precipitation Analysis (TMPA): Quasi-Global, Multiyear, Combined-Sensor Precipitation Estimates at Fine Scales. J. Hydrometeorol. 2007, 8, 38-55. [CrossRef]

15. Huffman, G.J.; Adler, R.F.; Bolvin, D.T.; Nelkin, E.J. The TRMM multi-satellite precipitation analysis (TMPA). In Satellite Rainfall Applications for Surface Hydrology; Gebremichael, M., Hossain, F., Eds.; Springer: Dordrecht, The Netherlands, 2010; pp. 3-22.

16. Joyce, R.J.; Janowiak, J.E.; Arkin, P.A.; Xie, P.CMORPH: A Method that Produces Global Precipitation Estimates from Passive Microwave and Infrared Data at High Spatial and Temporal Resolution. J. Hydrometeorol. 2004, 5, 17. [CrossRef]

17. Sorooshian, S.; Hsu, K.-L.; Gao, X.; Gupta, H.V.; Imam, B.; Braithwaite, D. Evaluation of PERSIANN System Satellite-Based Estimates of Tropical Rainfall. Bull. Am. Meteorol. Soc. 2000, 81, 2035-2046. [CrossRef]

18. Huffman, G.J.; Bolvin, D.T.; Nelkin, E.J. Integrated Multi-Satellite Retrievals for GPM (IMERG) Technical Documentation. 2019; Volume 612. Available online: https://docserver.gesdisc.eosdis.nasa.gov/public/ project/GPM/IMERG_doc.06.pdf (accessed on 5 November 2020).

19. Prakash, S.; Sathiyamoorthy, V.; Mahesh, C.; Gairola, R.M. An evaluation of high-resolution multisatellite rainfall products over the Indian monsoon region. Int. J. Remote Sens. 2014, 35, 3018-3035. [CrossRef]

20. Satgé, F.; Bonnet, M.-P.; Gosset, M.; Molina, J.; Lima, W.H.Y.; Zolá, R.P.; Timouk, F.; Garnier, J. Assessment of satellite rainfall products over the Andean plateau. Atmos. Res. 2016, 167, 1-14. [CrossRef]

21. Satgé, F.; Espinoza, R.; Zolá, R.P.; Roig, H.; Timouk, F.; Molina, J.; Garnier, J.; Calmant, S.; Seyler, F.; Bonnet, M.-P. Role of Climate Variability and Human Activity on Poopó Lake Droughts between 1990 and 2015 Assessed Using Remote Sensing Data. Remote Sens. 2017, 9, 218. [CrossRef]

22. De Paiva, R.C.D.; Buarque, D.C.; Clarke, R.T.; Collischonn, W.; Allasia, D.G. Reduced precipitation over large water bodies in the Brazilian Amazon shown from TRMM data. Geophys. Res. Lett. 2011, 38. [CrossRef]

23. Tian, Y.; Peters-Lidard, C.D.; Choudhury, B.J.; Garcia, M. Multitemporal Analysis of TRMM-Based Satellite Precipitation Products for Land Data Assimilation Applications. J. Hydrometeorol. 2007, 8, 1165-1183. [CrossRef]

24. Dinku, T.; Ceccato, P.; Grover-Kopec, E.; Lemma, M.; Connor, S.J.; Ropelewski, C.F. Validation of satellite rainfall products over East Africa's complex topography. Int. J. Remote Sens. 2007, 28, 1503-1526. [CrossRef] 
25. Hirpa, F.A.; Gebremichael, M.; Hopson, T. Evaluation of High-Resolution Satellite Precipitation Products over Very Complex Terrain in Ethiopia. J. Appl. Meteorol. Clim. 2010, 49, 1044-1051. [CrossRef]

26. Satgé, F.; Zolá, R.P.; Bonnet, M.-P.; Hussain, B.M.; Martinez-Carvajal, H.; Akhter, G.; Uagoda, R. Benefits of the Successive GPM Based Satellite Precipitation Estimates IMERG-V03, -V04, -V05 and GSMaP-V06, -V07 Over Diverse Geomorphic and Meteorological Regions of Pakistan. Remote Sens. 2018, 10, 1373. [CrossRef]

27. Sun, Q.; Miao, C.; Duan, Q.; Ashouri, H.; Sorooshian, S.; Hsu, K. A Review of Global Precipitation Data Sets: Data Sources, Estimation, and Intercomparisons. Rev. Geophys. 2018, 56, 79-107. [CrossRef]

28. Bookhagen, B.; Burbank, D.W. Topography, relief, and TRMM-derived rainfall variations along the Himalaya. Geophys. Res. Lett. 2006, 33. [CrossRef]

29. Milewski, A.; Elkadiri, R.; Durham, M. Assessment and Comparison of TMPA Satellite Precipitation Products in Varying Climatic and Topographic Regimes in Morocco. Remote Sens. 2015, 7, 5697-5717. [CrossRef]

30. Satgé, F.; Xavier, A.; Zolá, R.P.; Hussain, Y.; Hussain, Y.; Garnier, J.; Bonnet, M.-P. Comparative Assessments of the Latest GPM Mission's Spatially Enhanced Satellite Rainfall Products over the Main Bolivian Watersheds. Remote Sens. 2017, 9, 369. [CrossRef]

31. Ullah, W.; Wang, G.; Ali, G.; Hagan, D.F.T.; Bhatti, A.S.; Lou, D. Comparing Multiple Precipitation Products against In-Situ Observations over Different Climate Regions of Pakistan. Remote Sens. 2019, 11, 628. [CrossRef]

32. Yong, B.; He, X.; Ren, L.-L.; Yong, B.; Huffman, G.J.; Chen, X.; Wang, W.; Khan, S.I. Assessment of evolving TRMM-based multisatellite real-time precipitation estimation methods and their impacts on hydrologic prediction in a high latitude basin. J. Geophys. Res. Space Phys. 2012, 117. [CrossRef]

33. Hussain, Y.; Satgé, F.; Hussain, M.B.; Martinez-Carvajal, H.; Bonnet, M.-P.; Cárdenas-Soto, M.; Roig, H.L.; Akhter, G. Performance of CMORPH, TMPA, and PERSIANN rainfall datasets over plain, mountainous, and glacial regions of Pakistan. Theor. Appl. Clim. 2017, 131, 1119-1132. [CrossRef]

34. Gaona, M.F.R.; Overeem, A.; Leijnse, H.; Uijlenhoet, R. First-Year Evaluation of GPM Rainfall over the Netherlands: IMERG Day 1 Final Run (V03D). J. Hydrometeorol. 2016, 17, 2799-2814. [CrossRef]

35. Liu, Z. Comparison of Integrated Multisatellite Retrievals for GPM (IMERG) and TRMM Multisatellite Precipitation Analysis (TMPA) Monthly Precipitation Products: Initial Results. J. Hydrometeorol. 2016, 17, 777-790. [CrossRef]

36. Prakash, S.; Mitra, A.K.; Pai, D.; AghaKouchak, A. From TRMM to GPM: How well can heavy rainfall be detected from space? Adv. Water Resour. 2016, 88, 1-7. [CrossRef]

37. Rozante, J.R.; Vila, D.A.; Chiquetto, J.B.; Fernandes, A.D.A.; Alvim, D.S. Evaluation of TRMM/GPM Blended Daily Products over Brazil. Remote Sens. 2018, 10, 882. [CrossRef]

38. Salles, L.; Satgé, F.; Roig, H.; Almeida, T.; Olivetti, D.; Ferreira, W. Seasonal Effect on Spatial and Temporal Consistency of the New GPM-Based IMERG-v5 and GSMaP-v7 Satellite Precipitation Estimates in Brazil's Central Plateau Region. Water 2019, 11, 668. [CrossRef]

39. Xu, F.; Guo, B.; Ye, B.; Ye, Q.; Chen, H.; Ju, X.; Guo, J.; Wang, Z. Systematical Evaluation of GPM IMERG and TRMM 3B42V7 Precipitation Products in the Huang-Huai-Hai Plain, China. Remote Sens. 2019, 11, 697. [CrossRef]

40. Arvor, D.; Funatsu, B.M.; Michot, V.; Dubreuil, V. Monitoring Rainfall Patterns in the Southern Amazon with PERSIANN-CDR Data: Long-Term Characteristics and Trends. Remote Sens. 2017, 9, 889. [CrossRef]

41. Bai, X.; Shen, W.; Wu, X.; Wang, P. Applicability of long-term satellite-based precipitation products for drought indices considering global warming. J. Environ. Manag. 2020, 255, 109846. [CrossRef]

42. Novella, N.S.; Thiaw, W.M. African Rainfall Climatology Version 2 for Famine Early Warning Systems. J. Appl. Meteorol. Clim. 2013, 52, 588-606. [CrossRef]

43. Satgé, F.; Hussain, Y.; Xavier, A.; Zolá, R.P.; Salles, L.; Timouk, F.; Seyler, F.; Garnier, J.; Frappart, F.; Bonnet, M.-P. Unraveling the impacts of droughts and agricultural intensification on the Altiplano water resources. Agric. For. Meteorol. 2019, 279, 107710. [CrossRef]

44. Beck, H.E.; Van Dijk, A.I.J.M.; Levizzani, V.; Schellekens, J.; Miralles, D.G.; Martens, B.; De Roo, A. MSWEP: 3-hourly $0.25^{\circ}$ global gridded precipitation (1979-2015) by merging gauge, satellite, and reanalysis data. Hydrol. Earth Syst. Sci. 2017, 21, 589-615. [CrossRef]

45. Satgé, F.; Hussain, Y.; Molina-Carpio, J.; Pillco, R.; Laugner, C.; Akhter, G.; Bonnet, M. Reliability of SM2RAIN precipitation datasets in comparison to gauge observations and hydrological modelling over arid regions. Int. J. Clim. 2020, 6704. [CrossRef] 
46. Abiola, S.F.; Mohd-Mokhtar, R.; Ismail, W.; Mohamad, N. Categorical statistical approach to satellite retrieved rainfall data analysis in Nigeria. Sci. Res. Essays 2013, 8, 2123-2137. [CrossRef]

47. Akinyemi, D.F.; Ayanlade, O.S.; Nwaezeigwe, J.O.; Ayanlade, A. A Comparison of the Accuracy of Multi-satellite Precipitation Estimation and Ground Meteorological Records Over Southwestern Nigeria. Remote Sens. Earth Syst. Sci. 2020, 3, 1-12. [CrossRef]

48. Usman, M.; Nichol, J.E.; Ibrahim, A.T.; Buba, L.F. A spatio-temporal analysis of trends in rainfall from long term satellite rainfall products in the Sudano Sahelian zone of Nigeria. Agric. For. Meteorol. 2018, 260-261, 273-286. [CrossRef]

49. Abiodun, B.J.; Adeyewa, Z.D.; Oguntunde, P.G.; Salami, A.T.; Ajayi, V.O. Modeling the impacts of reforestation on future climate in West Africa. Theor. Appl. Clim. 2012, 110, 77-96. [CrossRef]

50. Akinsanola, A.A.; Ogunjobi, K.O.; Ajayi, V.O.; Adefisan, E.A.; Omotosho, J.A.; Sanogo, S. Comparison of five gridded precipitation products at climatological scales over West Africa. Theor. Appl. Clim. 2017, 129, 669-689. [CrossRef]

51. Akpodiogaga-a, P.; Odjugo, O. General Overview of Climate Change Impacts in Nigeria. J. Hum. Ecol. 2010, 29, 47-55. [CrossRef]

52. Chineke, T.C.; Jagtap, S.S.; Nwofor, O. West African monsoon: Is the August break "breaking" in the eastern humid zone of Southern Nigeria? Clim. Chang. 2010, 103, 555-570. [CrossRef]

53. Funk, C.; Peterson, P.; Landsfeld, M.; Pedreros, D.; Verdin, J.; Shukla, S.; Husak, G.; Rowland, J.; Harrison, L.; Hoell, A.; et al. The climate hazards infrared precipitation with stations-A new environmental record for monitoring extremes. Sci. Data 2015, 2, 150066. [CrossRef] [PubMed]

54. Beck, H.E.; Wood, E.F.; Pan, M.; Fisher, C.K.; Miralles, D.G.; Van Dijk, A.I.J.M.; McVicar, T.R.; Adler, R.F. MSWEP V2 Global 3-Hourly $0.1^{\circ}$ Precipitation: Methodology and Quantitative Assessment. Bull. Am. Meteorol. Soc. 2019, 100, 473-500. [CrossRef]

55. Ashouri, H.; Hsu, K.-L.; Sorooshian, S.; Braithwaite, D.K.; Knapp, K.R.; Cecil, L.D.; Nelson, B.R.; Prat, O.P. PERSIANN-CDR: Daily Precipitation Climate Data Record from Multisatellite Observations for Hydrological and Climate Studies. Bull. Am. Meteorol. Soc. 2015, 96, 69-83. [CrossRef]

56. Hsu, K.-L.; Gao, X.; Sorooshian, S.; Gupta, H.V. Precipitation Estimation from Remotely Sensed Information Using Artificial Neural Networks. J. Appl. Meteorol. 1997, 36, 1176-1190. [CrossRef]

57. Maidment, R.I.; Grimes, D.; Allan, R.P.; Tarnavsky, E.; Stringer, M.; Hewison, T.; Roebeling, R.; Black, E. The 30 year TAMSAT African Rainfall Climatology and Time series (TARCAT) data set. J. Geophys. Res. Atmos. 2014, 119, 10619-10644. [CrossRef]

58. Tarnavsky, E.; Grimes, D.; Maidment, R.; Black, E.; Allan, R.P.; Stringer, M.; Chadwick, R.; Kayitakire, F. Extension of the TAMSAT Satellite-Based Rainfall Monitoring over Africa and from 1983 to Present. J. Appl. Meteorol. Clim. 2014, 53, 2805-2822. [CrossRef]

59. Xie, P.; Joyce, R.; Wu, S.; Yoo, S.-H.; Yarosh, Y.; Sun, F.; Lin, R. Reprocessed, Bias-Corrected CMORPH Global High-Resolution Precipitation Estimates from 1998. J. Hydrometeorol. 2017, 18, 1617-1641. [CrossRef]

60. Kubota, T.; Aonashi, K.; Ushio, T.; Shige, S.; Takayabu, Y.N.; Kachi, M.; Arai, Y.; Tashima, T.; Masaki, T.; Kawamoto, N.; et al. Global Satellite Mapping of Precipitation (GSMaP) Products in the GPM Era. In Satellite Precipitation Measurement; Levizzani, V., Kidd, C., Kirschbaum, D.B., Kummerow, C.D., Nakamura, K., Turk, F.J., Eds.; Springer International Publishing: Cham, Switzerland, 2020; pp. 355-373.

61. Ushio, T.; Sasashige, K.; Kubota, T.; Shige, S.; Okamoto, K.; Aonashi, K.; Inoue, T.; Takahashi, N.; Iguchi, T.; Kachi, M.; et al. A Kalman Filter Approach to the Global Satellite Mapping of Precipitation (GSMaP) from Combined Passive Microwave and Infrared Radiometric Data. J. Meteorol. Soc. Jpn. 2009, 87A, 137-151. [CrossRef]

62. Huffman, G.J.; Bolvin, D.T.; Braithwaite, D.; Hsu, K.; Joyce, R.; Xie, P.; Yoo, S.H. Algorithm Theoretical Basis Document (ATBD) Version 06. Natl. Aeronaut. Space Adm. 2019, 38. Available online: https: //eospso.gsfc.nasa.gov/sites/default/files/atbd/atbd-lis-01.pdf (accessed on 5 November 2020).

63. Satgé, F.; Defrance, D.; Sultan, B.; Bonnet, M.-P.; Seyler, F.; Rouché, N.; Pierron, F.; Paturel, J.-E. Evaluation of 23 gridded precipitation datasets across West Africa. J. Hydrol. 2020, 581, 124412. [CrossRef]

64. Gupta, H.V.; Kling, H.; Yilmaz, K.K.; Martinez, G.F. Decomposition of the mean squared error and NSE performance criteria: Implications for improving hydrological modelling. J. Hydrol. 2009, 377, 80-91. [CrossRef] 
65. Beck, H.E.; Pan, M.; Roy, T.; Weedon, G.P.; Pappenberger, F.; Van Dijk, A.I.J.M.; Huffman, G.J.; Adler, R.F.; Wood, E. Daily evaluation of 26 precipitation datasets using Stage-IV gauge-radar data for the CONUS. Hydrol. Earth Syst. Sci. 2019, 23, 207-224. [CrossRef]

66. Gebregiorgis, A.S.; Hossain, F. Understanding the Dependence of Satellite Rainfall Uncertainty on Topography and Climate for Hydrologic Model Simulation. IEEE Trans. Geosci. Remote Sens. 2013, 51, 704-718. [CrossRef]

67. Tian, Y.; Peters-Lidard, C.D.; Eylander, J.B.; Joyce, R.J.; Huffman, G.J.; Adler, R.F.; Hsu, K.-L.; Turk, F.J.; Garcia, M.; Zeng, J. Component analysis of errors in satellite-based precipitation estimates. J. Geophys. Res. Space Phys. 2009, 114, 24101. [CrossRef]

68. Satgé, F.; Ruelland, D.; Bonnet, M.-P.; Molina, J.; Pillco, R. Consistency of satellite-based precipitation products in space and over time compared with gauge observations and snow- hydrological modelling in the Lake Titicaca region. Hydrol. Earth Syst. Sci. 2019, 23, 595-619. [CrossRef]

69. Shrestha, N.K.; Qamer, F.M.; Pedreros, D.; Murthy, M.S.R.; Wahid, S.M.; Shrestha, M. Evaluating the accuracy of Climate Hazard Group (CHG) satellite rainfall estimates for precipitation based drought monitoring in Koshi basin, Nepal. J. Hydrol. Reg. Stud. 2017, 13, 138-151. [CrossRef]

70. Maidment, R.I.; Grimes, D.; Black, E.; Tarnavsky, E.; Young, M.; Greatrex, H.; Allan, R.P.; Stein, T.H.M.; Nkonde, E.; Senkunda, S.; et al. A new, long-term daily satellite-based rainfall dataset for operational monitoring in Africa. Sci. Data 2017, 4, 170063. [CrossRef]

71. Muhammad, W.; Yang, H.; Lei, H.; Muhammad, A.; Yang, D. Improving the Regional Applicability of Satellite Precipitation Products by Ensemble Algorithm. Remote Sens. 2018, 10, 577. [CrossRef]

72. Rahman, K.U.; Shang, S.; Shahid, M.; Li, J. Developing an Ensemble Precipitation Algorithm from Satellite Products and Its Topographical and Seasonal Evaluations over Pakistan. Remote Sens. 2018, 10, 1835. [CrossRef]

73. Ma, Y.; Yang, Y.; Han, Z.; Tang, G.; Maguire, L.; Chu, Z.; Hong, Y. Comprehensive evaluation of Ensemble Multi-Satellite Precipitation Dataset using the Dynamic Bayesian Model Averaging scheme over the Tibetan plateau. J. Hydrol. 2018, 556, 634-644. [CrossRef]

74. Bhuiyan, A.E.; Nikolopoulos, E.I.; Anagnostou, E.N. Machine Learning-Based Blending of Satellite and Reanalysis Precipitation Datasets: A Multiregional Tropical Complex Terrain Evaluation. J. Hydrometeorol. 2019, 20, 2147-2161. [CrossRef]

Publisher's Note: MDPI stays neutral with regard to jurisdictional claims in published maps and institutional affiliations.

(C) 2020 by the authors. Licensee MDPI, Basel, Switzerland. This article is an open access article distributed under the terms and conditions of the Creative Commons Attribution (CC BY) license (http://creativecommons.org/licenses/by/4.0/). 